\title{
VELE VAGY NÉLKÜLE? - A KÖZÉPISKOLAI FÖLDRAJZTANKÖNYVEK TANULÁSI FOLYAMATBAN BETÖLTÖTT SZEREPÉNEK VIZSGÁLATA
}

With or without it? - Examining the role of high school geography textbooks in the process of learning

\section{GERLANG VIVIEN}

ELTE TTK Földrajz- és Földtudományi Intézet, Földrajz szakmódszertani csoport gerlang.vivien@gmail.com

\begin{abstract}
Textbooks are the most widely used and most well-known teaching aids, even today. They fulfil several educational functions throughout students' schooling, however, they textbooks are used less and less. The aim of this study is to detect what is the role of geography textbooks during the learning process of 9 th and 10th graders.
\end{abstract}

Keywords: textbook usage, geography textbook

\section{BEVEZETÉS}

A tankönyvek évszázadok óta a legelterjedtebb taneszközök, amelyek az egyes tantárgyak tantervben meghatározott oktatási-nevelési céljait hivatottak közvetíteni a köznevelés szereplői felé (NÁDASı A. 2014). A tankönyvek szerkesztésekor cél, hogy azok az életkori sajátosságoknak megfelelő tartalmúak és nyelvezetủek legyenek (KARLOVITZ J. 2000), a gyakorlatban mégis sok panasz érkezik azok felhasználhatóságára (KoJANITZ L. 2004), és ellentmondás húzódik az iskolában elsajátított tudás és annak életben való alkalmazhatósága között (CsAPó B. 2008). Sokféle tankönyv volt forgalomban a történelem során, melyek mindig magukon hordozták a kor oktatási-nevelési elméleteinek vonásait. A tankönyvi dizájn, a szerkezet, a felépítés is mind pedagógiai és módszertani célokat testesítenek meg.

A földrajzkönyvek az utóbbi években jelentős változáson mentek keresztül, egyre nagyobb súlyt fektetve a készség- és kompetenciafejlesztésre (MAKádi M. 2019). Miközben továbbra is a tankönyvek a legfontosabb és legszélesebb körben elérhetö tanulást segítő eszközök hazánkban, a tapasztalatok azt mutatják, hogy egyre kisebb arányban készülnek fel azokból a tanulók. Mi lehet a tankönyvi tanulás sikertelenségének az oka? 
A tankönyv segítségével történő ismeretszerzés alapfeltétele, hogy a tanuló értse, amit olvas, képes legyen elkülöníteni a lényeges információkat a lényegtelenektől. A PISAmérések rávilágítanak arra, hogy a magyarországi tizenévesek szövegértési képességei elmaradnak a kívánt szinttől. Ugyan a korábbi évek gyengülő tendenciájának véget vetett 2018-ban, hogy az akkori mérés során hattal több pontot értek el középiskolásaink, mint a megelőző mérésen, így is az OECD-átlag alatt végzett hazánk (PISA 2018. Összefoglaló jelentés). Összességében az eredmények tükrében inkább mondhatjuk, hogy romlik vagy stagnál a szint, de jelentős növekedésről semmiképp sem beszélhetünk. A szövegértési nehézség a szaktárgyak tanulása során is hátrányt jelent. A hosszabb, szaktudományos nyelvezetű szövegek értelmezése és a lényegkiemelés problémát okoz a tanulóknak, ami frusztrációhoz és a tanulási motiváció elvesztéséhez vezethet (KoJANITz L. 2004).

\section{A TANKÖNYVEK SZEREPE A TANULÁSI FOLYAMATBAN}

\section{A tankönyvek funkciói}

Ahhoz, hogy a tankönyvek szerepét részletezni tudjuk, először azt szükséges tisztázni, hogy mit tekintünk tankönyvnek. Definíciója számos szakirodalomban megjelenik, ám nincs egységesen elfogadott meghatározás, a különböző nézőpontok mind más jellemzőket emelnek ki. „A tankönyv fogalma oktatáspolitikai és oktatástechnológiai változásokat követve folyamatosan és dinamikusan változik" (Dringó-Horváth I. - MENYHeI Zs. 2020. p. 51.). Egyesek minden olyan könyvet tankönyvnek minősítenek, ami az ismeretek bővítését szolgálja. ÁвRанÁм I. (1993) rávilágít arra, hogy ez az értelmezés nem elég körülhatárolt, hiszen így számos olyan anyag is tankönyvnek számítana, ami a legkevésbé sem teljesít oktatási célokat. KAPOsi J. (2012) szerint tankönyvnek tekinthető minden oktatásban felhasznált könyv is, nem kizárólag a kifejezetten az oktatás számára készítettek. KARLOVITz J. (2000) a jogi oldalt figyelembe véve megállapítja, hogy „a tankönyv védelem alá eső alkotás, más megközelítésben az a könyv (elektronikus médium) védett, amelyet az adott országban (régióban) illetékes elfogadó (minisztérium, bizottság, iskolafenntartó, iskolai tantestület stb.) tankönyvként jóváhagy, iskolai használatra bevezet”. Számos elmélet olvasható a BÁTHORY Z. - FALUS I. (1997) által szerkesztett pedagógiai lexikon köteteiben is a tankönyvekkel kapcsolatban. Ezen értelmezések föbb közös vonásai alapján azt mondhatjuk, hogy a tankönyv olyan oktatási-nevelési eszköz, amely a didaktikai és pedagógiai elveket egyaránt alkalmazva segíti a tanuló ismeretszerzési, készségfejlesztési folyamatát a tantervben meghatározott célokkal összhangban, a szaktárgy sajátosságainak figyelembe vételével. Ez utóbbi meghatározás szellemében beszélünk a továbbiakban a tankönyvi funkciókról. 
A „mire jó a tankönyv?” kérdés hallatán mindenkinek azonnal az a kézenfekvő válasz jut eszébe: segíti az ismeretszerzést, releváns információkat szerezhetünk általa. Ennél azonban sokkal szerteágazóbb szerepkörrel rendelkezik, egyszerre nevel és oktat. Hogy végül jónak ítélünk-e meg egy tankönyvet, lényegében azon múlik, mennyiben teljesíti az elvárásainkat. Preferenciáink szerint szempontokat állítunk fel, amelyek értékelésünk alapját képezik. Ez nyilvánvalóan emberenként különböző és sok tényező függvénye. Tudományos szemmel vizsgálva számtalan kritériumrendszert találhatunk a tankönyvek minőségének értékelésére vonatkozóan. Ezek fő elemeikben nem különböznek, sokkal inkább a rendszerező elvek és a struktúra tekintetében találunk különbségeket (KoJAnITz L. 2007). A többféle megközelítés közül most a strukturális elemeket középpontba állító statikus értékelésről, valamint a funkciók alapján csoportosító dinamikus értékelésről lesz részletesebben szó. A statikus értékelés során az egyes szerkezeti összetevők meglétét nézik, továbbá azt, hogy ezek képesek-e betölteni a szerepüket. Az elemzés szempontját tehát a tankönyvi alkotóelemek, vagyis a szövegek és a szövegen kívüli egyéb összetevők (kérdések, feladatok, táblázatok, térképek, ábrák, képek, alkalmazott jelölések) adják. Ezzel szemben a dinamikus értékelés szempontjait a tankönyvi funkciók határozzák meg, azok alkotják a minőségi értékelés kritériumrendszerét (GÉcZiné LASKAI J. 2010).

Nemzetközi és a hazai szakirodalmak egyaránt foglalkoznak a tankönyvi funkciók meghatározásával, és bár különböző kategóriákat különböztetnek meg, találhatunk közös elemeket. Kojanitz L. (2007) tíz funkciót különböztet meg, amelyek három nagyobb cél köré csoportosíthatók (1. ábra). Az egyes funkciók egyben a tankönyvek

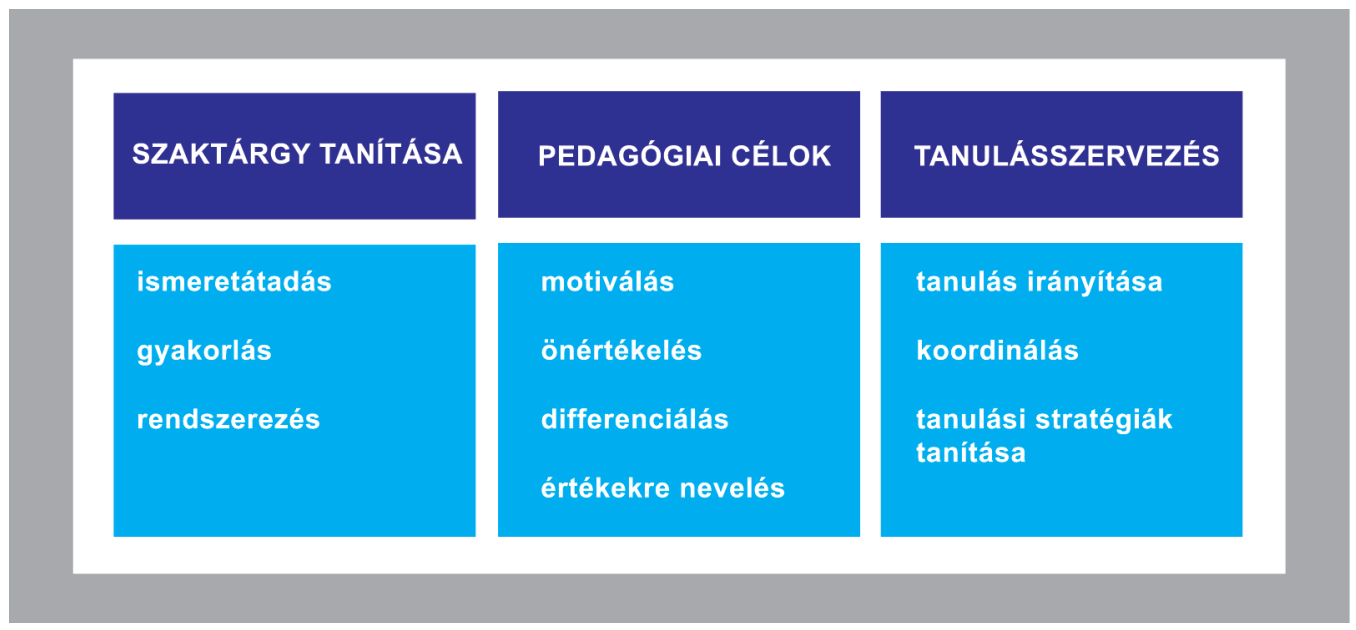

1. ábra. A tankönyvi funkciók rendszere (KoJANitz L. 2007 nyomán szerk. Gerlang V.) 
tanításban betöltött szerepét is leírják. A tankönyv funkciói lépten-nyomon utolérhetök, szövegében, feladatrendszerében, illusztrációiban egyaránt megmutatkoznak (KARLOvitz J. T. 2000), így ezen összetevők mindegyikének vizsgálata szükséges, ha a tankönyv minőségét szeretnénk megállapítani.

\section{Információhordozók a földrajzkönyvekben}

A tankönyvek felépítése, tartalma, szemléletmódja, feladattípusai és szemléltetőeszközei térben és időben egyaránt változtak. Pályafutásuk a kora középkorra nyúlik vissza, az első hazai tankönyv pedig Szent István uralkodásának idejére tehető. Azonban a tankönyvek csak a 15. században, a technika fejlődésével és ennek következtében a könyvnyomtatás feltalálásával kezdhették meg valódi hódító útjukat.

A mai tankönyvek a megértés és az elmélyítés érdekében illusztrációkban gazdagok, számtalan táblázatot, fotót, ábrát, azon belül pedig térképeket, diagramokat, folyamatábrákat tartalmaznak. Az ismeretszerzés szempontjából döntő jelentőségük van a tankönyvi ábráknak, hiszen az összetett valós folyamatok egyszerűsített megjelenítésével az elvont ismeretek is kézzelfoghatóbbá, így megérthetőbbé válnak, ami segíti a helyes képzetek kialakulását (PAIvio, A. 2007).

A jelenlegi újgenerációs földrajzkönyvekben a szöveg tagoltabb, mint a korábbi változatokban, a törzsszövegtől külön, színes szövegdobozokban olvasmányok, érdekességek foglalnak helyet, a témakörök végén a kulcsfogalmak külön ki vannak emelve, a leckéhez kapcsolódó kérdések pedig a lap szélén, valamint az aktuális ábrához kapcsolva találhatók. Kifejezetten nagy súlyt fektetnek a szemléltetésre, valamint a szemléletfejlesztésre, amit térképvázlatok, tematikus térképek, diagramok, mozaikábrák, infografikák és fotók egyaránt támogatnak. A rendszerezést és az összefüggések, folyamatok elsajátítását táblázatok, gondolattérképek, idővonalak, valamint folyamatábrák segítik.

Az újgenerációs tankönyvcsalád felépítésében törekszik a fokozatosságra. 7-8. évfolyamon a leíró részek hangsúlyosak, amivel a leírási algoritmusok megfelelő elsajátíttatása a cél. Középiskolában a szövegek aránya csökken, helyüket a tanulási folyamatban a sok ábra és kép veszi át, amik a leckék alapját képezik, kérdésekkel és feladatokkal irányítva, egyéni, páros, valamint csoportmunkában egyaránt megvalósítható tevékenységekkel. Mind a négy évfolyam tankönyvére igaz, hogy középpontjukban a készség- és kompetenciafejlesztés áll a tantervi követelmények és az iskolán kívül is hasznos tudás megszerzésének kívánalmával együtt (MAKÁDI M. 2019). 


\section{Tankönyvek korlátai}

Az IKT-eszközök és ezzel összefüggésben a digitális oktatási segédanyagok mind szélesebb elterjedése a tankönyveknek a köznevelési folyamatban való súlyát is megváltoztatta, elmondható, hogy az információs-kommunikációs technológiák visszaszorították a korábban egyeduralkodó segédeszközt. A digitális megoldások elsősorban a motiválás terén lehetnek hatékonyabbak a hagyományos tankönyveknél, de sikerükhöz napjaink társadalmi elvárásai is hozzájárulhatnak. Megállapítható továbbá, hogy a tankönyvek kevésbé rugalmasak, mint a digitális taneszközök, hiszen a benne leírtak nehezebben változtathatók, így amennyiben új tudományos felismerést szeretnének közölni, az nem lehetséges azonnal. A különféle tankönyvi ábrák nagyban hozzájárulhatnak a tanulói ismeretszerzéshez, azonban - különösen a földrajztanulás szempontjából - lényeges, hogy a tanulók a folyamatokat is átlássák, ami a statikus tankönyvi ábrákkal nehezebb, mint más dinamikus vizuális eszközök segítségével. Számtalan videó, animáció, szimuláció áll rendelkezésre, amelyek a földrajzi folyamatokat modellezik, ezáltal a mélyebb megismerést támogatják.

A mai köznevelés egyre eltökéltebb szándéka a digitális technikák oktatásban való felhasználása, ezzel összefüggésben pedig a tanulók digitális kompetenciájának fejlesztése. Erre számtalan példát láthatunk az újgenerációs földrajzkönyvekben is. Többek között az egyes feladatok megoldásához az interneten kell böngészni, valamint a leckék gyakran QR-kódokkal vannak kiegészítve, amelyeknek a leolvasásával a tanulók közvetlenül jutnak a megtekintésre szánt weblapra. A QR-kódok hidat képeznek a papíralapú és a digitális világ között, ezzel adva új keretet a tanulásnak, ám használatuk még nem teljeskörü, többnyire csak extra információkat, érdekességeket érnek el általuk a tanulók, nem a megértést szolgáló modelleket, vagyis a QR-kódokba rejtett weblapok nem szerves részei a leckéknek, csak kiegészítik azokat.

A jelenlegi tankönyvek közül néhány mindenki számára ingyenesen elérhető, akár digitális változatban is, azonban helyesebb lenne ezt digitalizált változatnak nevezni. Ugyanis fontos megjegyezni, hogy a digitalizált és a digitális tananyag nem ugyanaz. Míg a digitalizált tananyag a hagyományos nyomtatásban is megjelenő tankönyvek elektronikus változata, addig a digitális tananyag interaktív tartalmakat is tartalmazó segédanyag, beépített videóik, szimulációik, interaktív feladataik segítik a leckék feldolgozását. Hazánkban interaktív okoskönyvével évek óta elérhető digitális tananyagot kínál a Mozaik Kiadó, és 2020 tavaszán a Nemzeti Köznevelési Portál is nyilvánossá tette anyagait a koronavírus járvány miatt kialakult digitális tanrendre való átállás segítésére.

Természetesen a tankönyvek által kínált lehetőségek - legyenek azok hagyományos vagy digitális megoldások - csak akkor lehetnek hatékonyak, ha a megfelelően 
alkalmazzák azokat. A tankönyv elsősorban a tanulók segédeszköze, ami tereli őket az ismeretszerzés, a tudásépítés rögös útján, de a tanár felelössége, hogy megismertesse tanítványaival és megtanítsa nekik a használatát. Ennél fogva döntő jelentőségü, hogy a tankönyv tud-e elég megnyerő lenni a tanár számára, mennyire érzi logikusnak a felépítését, tartja megfelelőnek a tananyagok mélységét, szemléletesnek a vizuális anyagát.

Összességében a mai földrajzkönyvek tartalma, felépítése és feladattípusai egyaránt a modern pedagógiai irányzatokat képviselik, ráadásul bárki számára ingyenesen elérhetők. A tapasztalat mégis azt mutatja, hogy a tanulók nem szívesen használják azokat a tanulási folyamat során. Ez a tapasztalat indította el azt a földrajzkönyvek használatával kapcsolatos kutatást, amelynek eredményeit a továbbiakban ismertetem.

\section{KUTATÁS A FÖLDRAJZ TANULÁSA SORÁN TÖRTÉNÖ TANKÖNYVHASZNÁLATI SZOKÁSOKRÓL}

\section{Minta- és adatgyüjtés}

A kutatásom fő célkitüzése az volt, hogy felmérjem, milyen arányban használják a földrajzkönyvet a tanítási órákon vagy az otthoni felkészülés során a 9-10. évfolyamos középiskolai tanulók, valamint amennyiben alkalmazzák, milyen tevékenységekkel kapcsolatban teszik ezt. Az információkat írásbeli kikérdezéssel gyűjtöttem, amely során többségében zárt vagy félig zárt típusú kérdéseket tartalmazó kérdőívet töltöttek ki a tanulók. A feltett kérdések egy részében a válaszadók nominális skálán jelölték a válaszaikat, ugyanakkor a legtöbb esetben kérdéscsoportos 5 fokú Likert-skálán értékeltek. Az adatok gyüjtése önszámlálás útján történt 2019 novemberében és decemberében.

A kutatásban 491 tanuló vett részt, akik mindegyike földrajzot jelenleg is tanuló 9-10. évfolyamos középiskolás. A válaszadók közül 183 fiú és 308 lány. A minta kiválasztásakor fontos szempont volt, hogy iskolatípus és földrajzi elhelyezkedés szempontjából is változatos képet mutasson annak érdekében, hogy a lehető legjobban tükrözze az országos helyzetet. A tanulók életkorát tekintve 53 fö 14 éves, 246 fö 15 éves, 165 fö 16 éves és 27 fö 17 éves. Összesen 16 osztály tanulói töltötték ki a kérdőívet, melyek között egy nyolcosztályos, négy hatosztályos, négy ötévfolyamos nyelvi előkészítős, valamint hét négyévfolyamos gimnáziumi csoport tagjai voltak. A kutatásba bevont intézmények között egyaránt volt állami, alapítványi és egyházi fenntartású. Földrajzi elhelyezkedésüket tekintve budapesti és vidéki, azon belül pedig kisebb községben és megyeszékhelyen lévő iskolák is részt vettek a vizsgálatban. A kérdőívek nagyszámú kitöltése előtt egy kisebb csoport adott válaszokat annak érdekében, hogy a kérdéseket pontosítani tudjam az észrevételeik alapján. 


\section{A kutatás hipotézise}

A kutatásnak az volt a fö hipotézise, hogy földrajzórákon a tankönyv nem hangsúlyos taneszköz, keveset alkalmazzák azt. További feltételezésem volt, hogy a tanórára való otthoni felkészülés elsődleges forrása nem a tankönyv, hanem a tanórai jegyzetek és az interneten található segédanyagok.

\section{A tanulói kérdőívek felépítése}

A tanulói kérdőívekben az anonimitást szem előtt tartva először néhány demográfiai adatot kellett megadni (nem, életkor, iskolatípus, iskola székhelye). Ezután a tanulóknak képek alapján meg kellett jelölniük, hogy melyik földrajzkönyvvel rendelkeznek. Akik azt jelölték, hogy nincsen földrajzkönyvük, azoknak arra a kérdésre is válaszolniuk kellett, hogy amennyiben lenne, használnák-e. Ezt követően a tankönyvhasználati szokásokra vonatkozó kérdéseket tettem fel először a tantárgyak összességére, majd speciálisan a földrajzra nézve. A továbbiakban három, általában a tankönyvhasználat gyakoriságára és a tanítási órákra való felkészülés segédanyagaira vonatkozó kérdést kaptak. Ezek egyrészt a ráhangolódást segítő bemelegítő kérdések szerepét töltötték be, másrészt segítségükkel meghatározható, hogy a földrajzkönyvek használata az általános tankönyvhasználati gyakorisághoz képest hol helyezkedik el. Az ezt követő három kérdés megfogalmazása nagyon hasonló volt, de ezek már kifejezetten a földrajz tankönyvvel való tanulására kérdeztek rá. Az utolsó, nyílt végü kérdésben a tanulóknak azt kellett megfogalmazniuk, hogy számukra mi fontos egy tankönyvben, mikor érzik azt jónak, használhatónak.

\section{A kérdőívekre adott tanulói válaszok}

A demográfiai adatok felvétele utáni első kérdésben a válaszadóknak öt lehetőség közül kellett kiválasztaniuk azt, hogy melyik tankönyvvel rendelkeznek. Egy-egy képet láttak az adott évfolyam újgenerációs földrajz tankönyvéről (ARDAY I. et al. 2018a, 2018b), az egykor a Nemzeti Tankönyvkiadó (Nemzedékek Tudása Tankönyvkiadó) által kiadott, az OFI által átvett tankönyvről (ProbÁld F. - ÜTőNÉ VISI J. 2014, NAGY B. et al. 2018) valamint 9. osztályban a Lakóhelyünk, a Föld címü (KereszTy P. et al. 2014), 10. évfolyamon pedig Az ember és a Föld címü (BERneK Á. 2016), ugyancsak a Nemzedékek Tudása Tankönyvkiadótól származó könyvről. Ezeken kívül két választási lehetőség állt rendelkezésre, az egyiket azoknak kellett jelölni, akiknek a könyve nem volt a felsoroltak között, a másikat pedig azoknak, akiknek nincs földrajzkönyvük. A válaszadók döntő többsége $(60,69 \%-a)$ az eredetileg a Nemzeti Tankönyvkiadó égisze alatt megjelent 
tankönyvből tanul, 31,77\% az OFI újgenerációs tankönyvcsaládjának valamely tagjából, és mindössze 2,85\% használja a Lakóhelyünk, a Föld címü könyvet. Olyan nem volt, aki a felsoroltakon kívül másból tanulna. Összesen 23 főnek (4,68\%) nincs semmilyen földrajzkönyve. A földrajzkönyvvel nem rendelkezők többsége (60,87\%) nem is vágyik rá, és akkor sem használná, ha lenne. 9 fó $(39,13 \%)$ szerint viszont nagy segítség lenne a tanulás során, ha el tudná olvasni az adott leckét a tankönyvben.

A következő kérdésblokkban arra kerestem választ, hogy milyen gyakran használnak tankönyvet az iskolai tanórákon. Az első kérdésre adott tanulói válaszok alapján (1. táblázat) az a következtetés vonható le, hogy a megkérdezettek közül elhanyagolhatóan kevesen vannak azok, akik egyáltalán nem használnak tankönyvet az iskolában (7 fö) és összesen 22 fö válaszolta azt, hogy minden órán van tankönyvhasználat. A tankönyvet nagyon ritkán (33,20\%), az órák nagyjából felében (31,16\%), illetve a tanórák többségén (29,74\%) használók aránya közel azonos volt.

Ezzel szemben a földrajzkönyvek használata egészen más képet mutat, mint az általános tankönyvhasználat. Itt a legkevesebben (mindösszesen 15 fö) a minden órán jellemző tankönyvhasználatot jelölték meg. Az órák többségében a válaszadók 17,71\%-a, az órák nagyjából felében 21,59\%-a alkalmazza. Ennél valamivel többen $(23,22 \%)$ nyilatkoztak úgy, hogy soha nem végeznek tankönyv segítségével tevékenységeket a földrajzórákon. A legtöbben $(34,42 \%)$ úgy érzik, hogy nagyon ritkán kerül sor tankönyvhasználatra.

A tankönyvekre általában, valamint a kifejezetten a földrajzkönyvre vonatkozó kérdésekre leggyakrabban megjelölt válasz mindkét esetben arról árulkodik, hogy nagyon ritkán használnak tankönyvet a középiskolákban. Azonban a többi válasz nagy eltérést mutat, míg az általános esetet vizsgálva a pontszám inkább a magasabb értékek felé tolódik, a földrajzkönyvek esetében zömében a soha, nagyon ritkán, illetve az órák nagyjából felében lehetőségek közül választottak. Következtetésképp földrajzkönyvet az átlagos tankönyvhasználatnál ritkábban alkalmaznak tanórai keretek között (2. ábra).

\begin{tabular}{|c|c|c|c|c|}
\hline \multirow[t]{2}{*}{ Értékelési skála } & \multicolumn{2}{|c|}{$\begin{array}{l}\text { Milyen gyakran használtok } \\
\text { tankönyvet tanórán? } \\
(\mathrm{N}=491)\end{array}$} & \multicolumn{2}{|c|}{$\begin{array}{l}\text { Milyen gyakran használtok } \\
\text { tankönyvet földrajzórán? } \\
(\mathrm{N}=491)\end{array}$} \\
\hline & fö & $\%$ & fö & $\%$ \\
\hline Soha (1) & 7 & 1,43 & 114 & 23,22 \\
\hline Nagyon ritkán (2) & 163 & 33,20 & 169 & 34,42 \\
\hline Az órák nagyjából felében (3) & 153 & 31,16 & 106 & 21,59 \\
\hline Többnyire, de nem minden órán (4) & 146 & 29,74 & 87 & 17,71 \\
\hline Minden órán (5) & 22 & 4,48 & 15 & 3,05 \\
\hline
\end{tabular}

1. táblázat. A tankönyvhasználat gyakorisága tanórákon (szerk. Gerlang V.) 


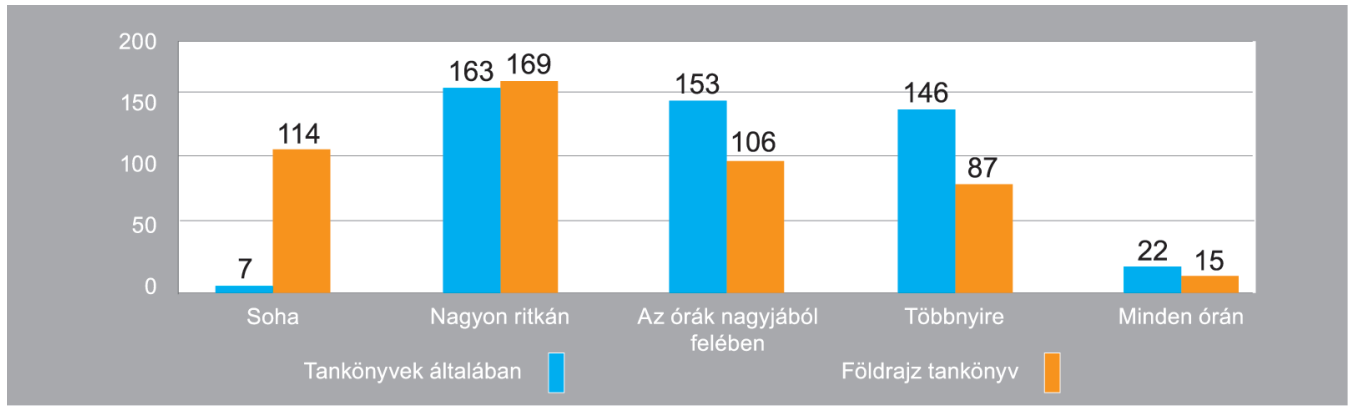

2. ábra. A tanórai, valamint kifejezetten a földrajzórai tankönyvhasználók száma (fö) (szerk. Gerlang V.)

A következőkben arról kellett nyilatkozniuk a tanulóknak, hogy a felsorolt tevékenységekkel kapcsolatban milyen gyakran kerül elő a tankönyv, valamint kifejezetten a földrajzkönyv. A megfogalmazott állításokat a 2. táblázat mutatja. Az állításokról a tanulóknak ötfokozatú rangskálán kellett bejelölniük, hogy mennyire tartják azt jellemzőnek. Az (1) szám jelentése az egyáltalán nem igaz, illetve soha, az (5) jelentése pedig a mindig, illetve minden tanórán (3. és 4. ábra).

A válaszokból az a következtetés vonható le, nem kifejezetten jellemző, hogy a tanórákon vagy speciálisan a földrajzórákon a tankönyvből szöveget olvassanak és dolgozzanak fel (mindkét esetben nagyjából a tanulók 60\%-a jelölte a soha vagy a nagyon ritkán válaszlehetőségeket). A második állításra vonatkozó eredmények alapján a tankönyvi szöveg önálló olvasása még kevésbé jellemző a tanítási órákon. Tantárgytól függetlenül a megkérdezettek nagyjából 73\%-a sohasem vagy nagyon ritkán dolgoz fel önállóan tankönyvi szöveget. A földrajzzal kapcsolatban 65\%-uk nyilatkozta azt, hogy soha, és több mint 20\%-uk azt, hogy az esetek túlnyomó többségében nem. A tankönyvi szöveg alapján való jegyzet készítésére hasonló arányban érkeztek válaszok.

\begin{tabular}{|c|c|}
\hline Állítás száma & Állitás \\
\hline 1. & A tanár vagy egy tanuló felolvas a tankönyvből egy-egy anyagrészt \\
\hline 2. & A tanulók némán olvasnak a tankönyvből a tanítási órán \\
\hline 3. & A tankönyvi szöveg alapján vázlatot vagy jegyzetet írunk \\
\hline 4. & A tankönyv képeit, ábráit, táblázatait, a térképeket közösen elemezzük \\
\hline 5. & A tankönyv képeit, ábráit, táblázatait, a térképeket önállóan elemezzük \\
\hline 6. & A tankönyvben lévő feladatokat kell megoldanunk az órán \\
\hline 7. & Házi feladatot kapunk a tankönyvből \\
\hline
\end{tabular}

2. táblázat. A tankönyvhöz kapcsolódó tevékenységek a tanórákon, illetve a földrajzórákon kérdéshez tartozó állitások 


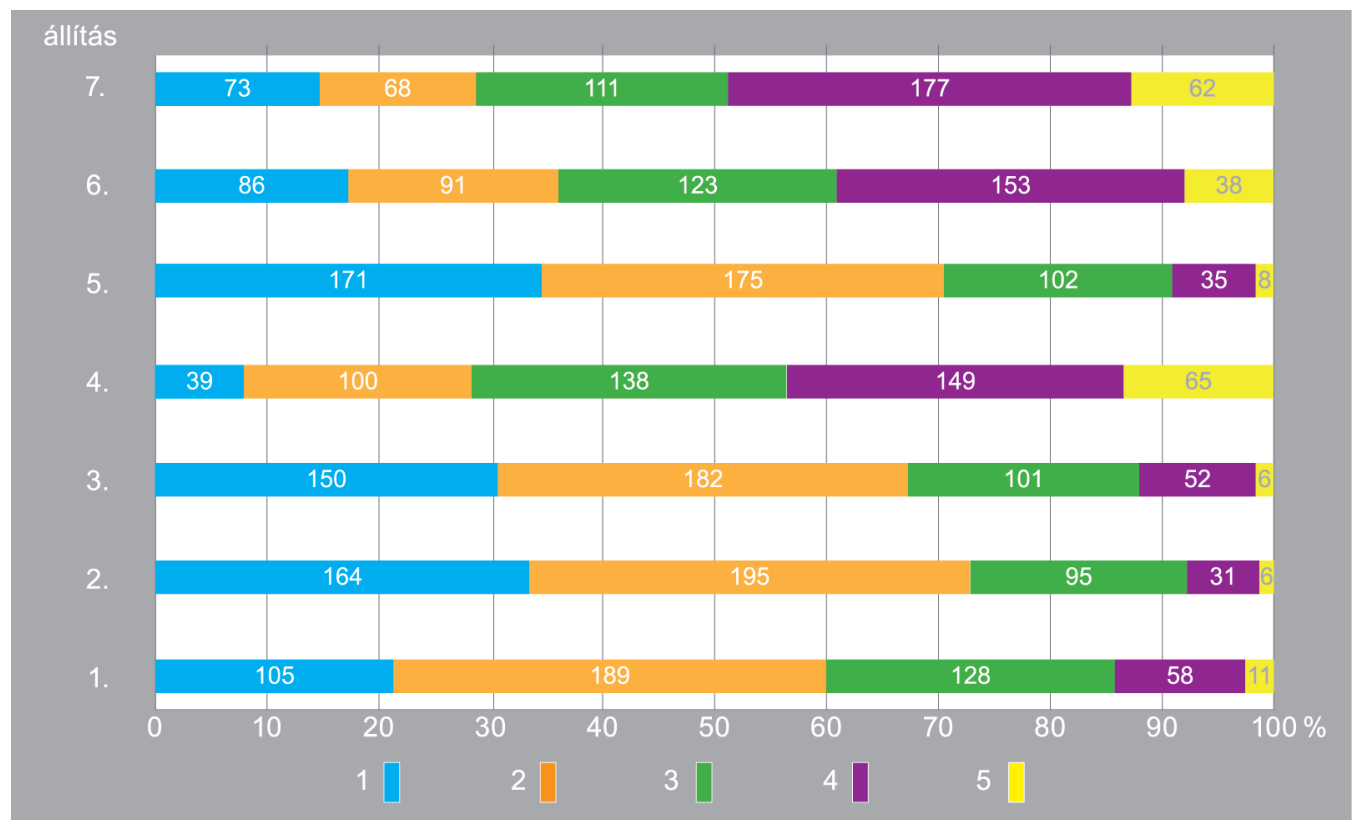

3. ábra. A tankönyvek felhasználási módja az iskolában (1 - egyáltalán nem, soha, 2 - ritkán, 3 - az esetek nagyjából felében, 4 - gyakran, 5 - mindig, minden órán. A diagramon feltüntetett számok az adott értékelést adók számát jelölik.) (szerk. Gerlang V.)

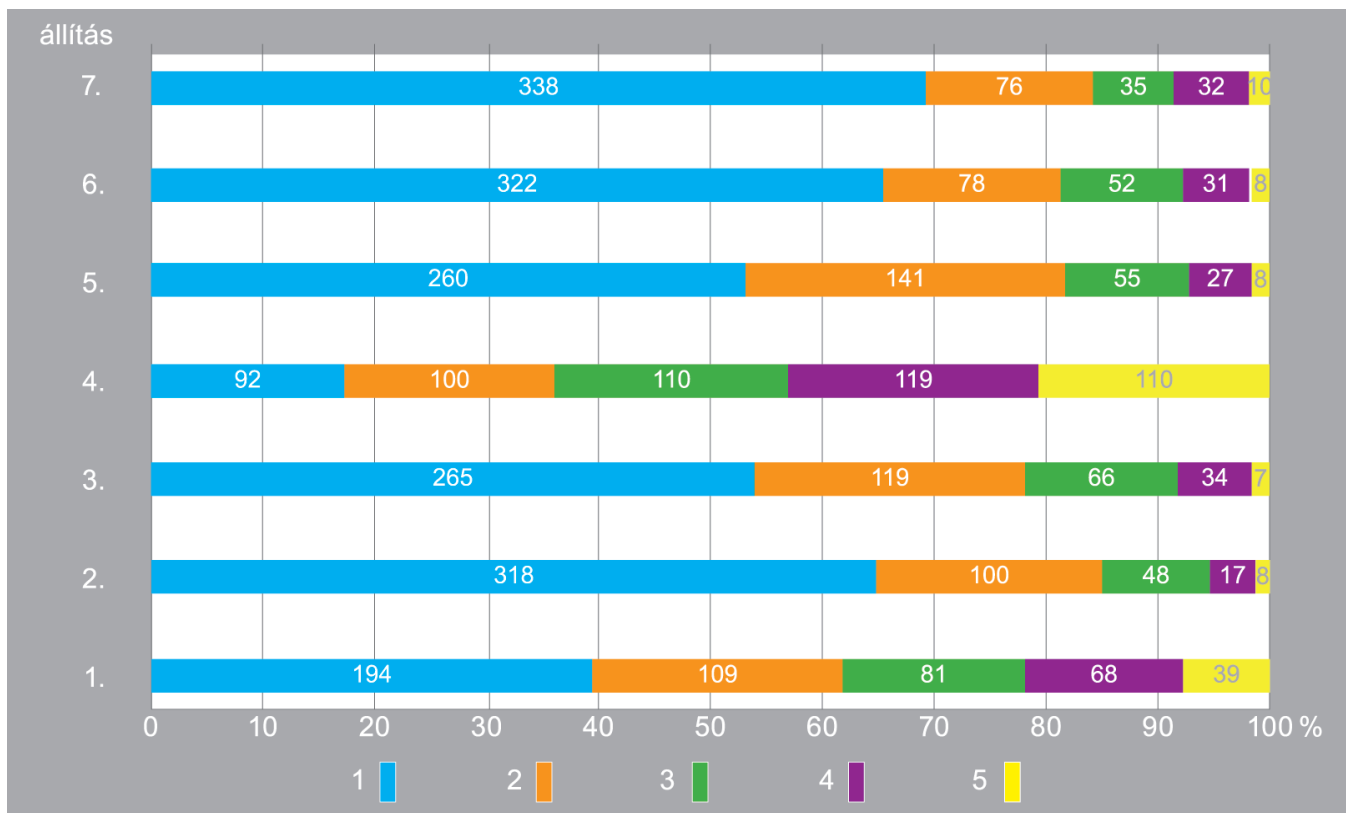

4. ábra. A földrajzkönyv felhasználási módja az iskolában (1 - egyáltalán nem, soha, 2 - ritkán, 3 -az esetek nagyjából felében, 4 - gyakran, 5 - mindig, minden órán. A diagramon feltüntetett számok az adott értékelést adók számát jelölik.) (szerk. Gerlang V.) 
A negyedik szempont a tankönyvekben található nem szöveges információhordozók (táblázatok, ábrák, képek, térképek) közös elemzésének gyakoriságára vonatkozott. Nem konkrét tantárgy esetében a legtöbben a gyakran és ennél valamivel kevesebben az órák nagyjából felében lehetőségeket jelölték meg. A soha és a minden órán opciót kevesen választották (8\%, valamint 13\%). A földrajzkönyvek szempontjából az órák nagyjából felében, a gyakran és a minden órán kategóriák mindegyikét csaknem ugyanannyian jelölték és alig több mint 30\%-uk nyilatkozott úgy, hogy sohasem vagy csak nagyon ritkán foglalkoznak a tankönyvi ábrákkal, képekkel. A tankönyvi ábrák, képek önálló elemzése tekintetében elmondható, hogy a tanulók döntő hányada (több mint 70\%-a) sohasem vagy csak nagyon ritkán kap ilyen feladatot, a földrajzra vonatkozóan pedig ez az arány még magasabb (81\%-nál is több). Összességében a megkérdezettek több mint fele egyáltalán nem értelmezi földrajzkönyve ábráit önállóan. A tankönyvi feladatok megoldása az iskolai tanórákon többnyire gyakori és közepesen gyakori, ezzel szemben földrajzórán egészen mást mutatnak a számok, a megkérdezettek több mint 65\%-a az egyáltalán nem jellemző lehetőséget jelölte. A tankönyvből kapott házi feladatok esetében is hasonló következtetéseket vonhatunk le, általában gyakran (36\%) vagy közepesen gyakran (22,6\%), míg a földrajzra vonatkozóan sohasem $(68,8 \%)$ valósul meg.

A következőkben a dolgozatokra és felelésekre való felkészülés segédanyagaira kérdeztem rá. A tantárgyak összességére, valamint a földrajzra vonatkozó feleletválasztós kérdéseknél nyolc felkészülési mód közül kellett a tanulóknak kiválasztani a rájuk leginkább jellemzőt (3. táblázat). Az utolsó választható lehetőség az egyéb kategóriája volt. Amennyiben nem talált a tanuló olyan állítást, ami illene a tanulási szokásaira, ezt kellett jelölnie és egyben meg is kellett neveznie, hogy ő milyen eszközt részesít elönyben. Mindösszesen 6 fő (1,22\%), a földrajz tanulására vonatkoztatva pedig 5 fő (a válaszadók nagyjából 1\%-a) jelölték az egyéb kategóriáját, és mindegyikük úgy nyilatkozott, hogy mindent használ, vagyis az órai jegyzeteket, a tankönyvet és az internetet egyaránt bevonja az otthoni felkészülésbe.

Ahogyan azt az 5. ábra is mutatja, az iskolai megmérettetésekre készülés legkedveltebb eszköze a tanulók körében az órai jegyzetek és internetes források együttes alkalmazása (32,99\%), ennél némileg kevesebben voksoltak az órai jegyzetek tankönyvvel való kiegészítésére (31,36\%). A harmadik helyen a kizárólag órai jegyzetekből való tanulás áll (23,63\%), míg a többi választási lehetőséget ezeknél jóval kevesebben jelölték. A földrajz tanulására vonatkozóan is ugyanazt a három felkészülési módot jelölték a legtöbben, azonban itt a csak jegyzetekből való tanulást jelentősen többen részesítették előnyben, mint a nem tárgyspecifikus kérdés esetén (a válaszadók 49\%-a). Ettől jóval elmarad az órai jegyzetek internettel való kiegészítése (20,77\%) és még kevesebben jelölték az órai jegyzetek és a tankönyvi szöveg kombinációját (17,31\%). Azokat a felkészülési módokat, 
ahol egyértelmüen a tankönyv hangsúlyos (tankönyvi szöveg olvasása, illetve abból vázlat készítése, a szöveg mellett ábrák és képek áttekintése) alig néhány tanuló jelölte, és akadtak olyanok is, akik egyáltalán nem készülnek otthon a megmérettetésekre $(6,31 \%)$, földrajzból pedig ennél is többen $(8,76 \%)$.

\begin{tabular}{|c|c|c|c|c|}
\hline \multirow[t]{2}{*}{ Felkészülési mód a tanitási órákra } & \multicolumn{2}{|c|}{$\begin{array}{l}\text { Általában a tantár- } \\
\text { gyakra vonatkozóan } \\
\text { (N=491) }\end{array}$} & \multicolumn{2}{|c|}{$\begin{array}{l}\text { Speciálisan a föld- } \\
\text { rajzra vonatkozóan } \\
(\mathrm{N}=491)\end{array}$} \\
\hline & fö & $\%$ & fö & $\%$ \\
\hline $\begin{array}{l}\text { Nem készülök otthon a dolgozatra, az órán megtanultakra } \\
\text { hagyatkozom. }\end{array}$ & 31 & 6,32 & 43 & 8,76 \\
\hline Csak az órán készített jegyzeteim alapján tanulok. & 116 & 23,63 & 241 & 49,08 \\
\hline $\begin{array}{l}\text { Elsősorban az órai jegyzeteket, vázlatokat tanulom, de } \\
\text { elolvasom a tankönyv szövegét is. }\end{array}$ & 154 & 31,36 & 85 & 17,31 \\
\hline $\begin{array}{l}\text { Az órai jegyzeteket, vázlatokat tanulom, de ha abból nem } \\
\text { értek valamit, akkor megkeresem az interneten. }\end{array}$ & 162 & 32,99 & 102 & 20,77 \\
\hline Csak a tankönyv szövegét olvasom. & 2 & 0,41 & 1 & 0,20 \\
\hline Elolvasom és kijegyzetelem a tankönyv szövegét. & 13 & 2,65 & 8 & 1,63 \\
\hline $\begin{array}{l}\text { Nem csak a tankönyv szövegét, hanem az ábrákat, képeket, } \\
\text { táblázatokat is tanulmányozom, válaszolok a kérdésekre. }\end{array}$ & 7 & 1,43 & 6 & 1,22 \\
\hline Egyéb. & 6 & 1,22 & 5 & 1,02 \\
\hline
\end{tabular}

3. táblázat. Különböző felkészülési módok gyakorisága általában a tanítási órákra és a földrajzórákra (szerk. Gerlang V.)

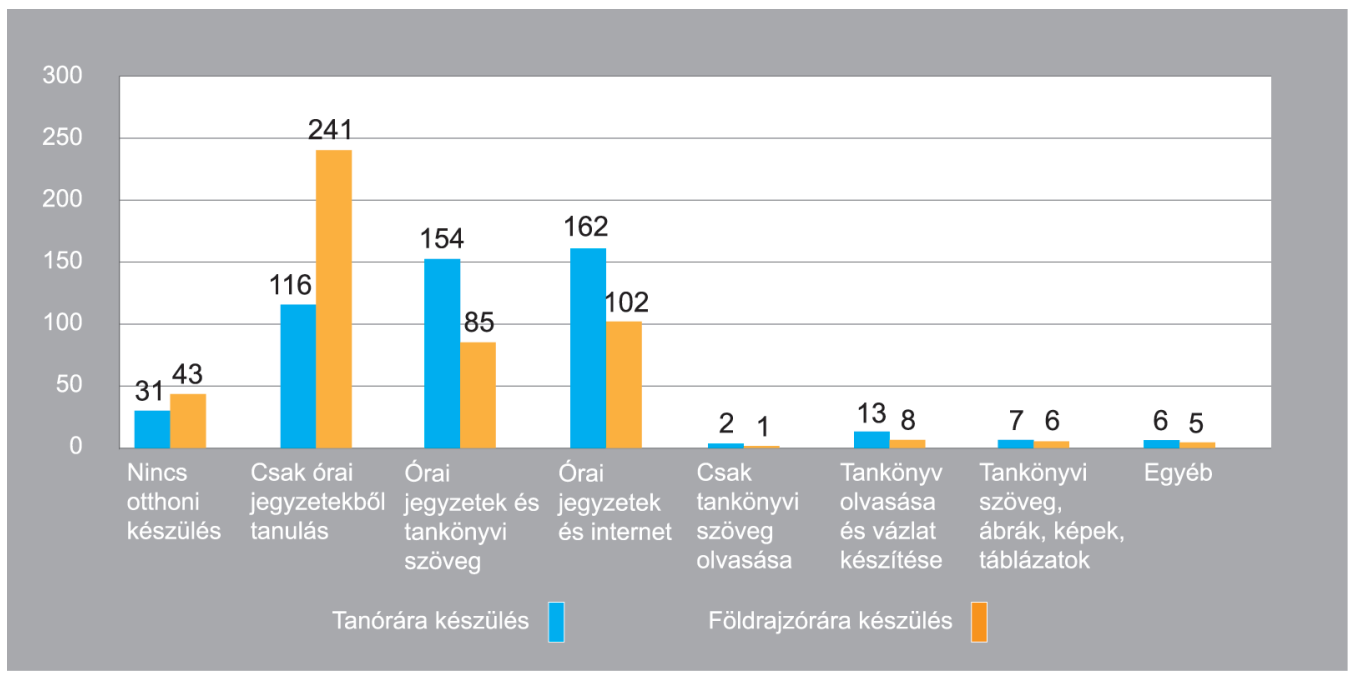

5. ábra. A tanulók tanórákra és kifejezetten a földrajzórákra való készülésének módjai (szerk. Gerlang V.) 
Ha az egyes válaszlehetőségeket csoportosítjuk, és aszerint vizsgáljuk, hogy a tanulók a felkészülés során igénybe veszik-e a tankönyvet bármilyen módon, akkor azt látjuk, hogy a tanulók 63\%-a nem vonja be a tanulási folyamatba a tankönyvet, a földrajzórára való rendszeres készülés során pedig még kevésbé számottevő ez az eszköz, mindöszszesen a megkérdezettek 21\%-a részesíti előnyben (6. ábra).

A kérdőív egy nyílt végü kérdéssel zárult, amiben arra kerestem a választ, hogy a tanulók milyen tankönyvből tanulnának szívesen, azok mely jellemzői teszik számukra érdekessé, használhatóvá. A tanulói vélemények szerint a jó tankönyvben sok az ábra és a kép, lényegre törő, érthetően megfogalmazott, nincs benne túl sok szakkifejezés, egyszerű a szövegezése, könnyen értelmezhető, nincs benne hosszú egybefüggő szöveg, aktuális (a közelmúlt eseményeiről is ír), vázlatos, tartalmaz érdekességeket is a törzsanyagon túl, jól elkülönülnek benne a fontos és a kiegészítő információk, felépítése logikus, tartalmaz fogalomtárat, vannak benne érdekes feladatok, színes, könnyü, lehetőleg elektronikusan is hozzáférhető.

Összességében az a kutatás tapasztalata, hogy a tankönyv sem a földrajzórai tanítás-tanulás folyamatában, sem az otthoni felkészülés során nem tölt be vezető szerepet. A tanulói válaszok arra engednek következtetni, hogy leginkább a tanítási órán készített jegyzetekből történik az ismeretek otthoni elsajátítása, a tankönyv szerepe ebben igen csekély, legyen szó a tantárgyak összességéről vagy csak a földrajzról. A tankönyvi szöveg olvasása, értelmezése különösen ritka tanórai és otthoni elfoglaltság. A nem szöveges

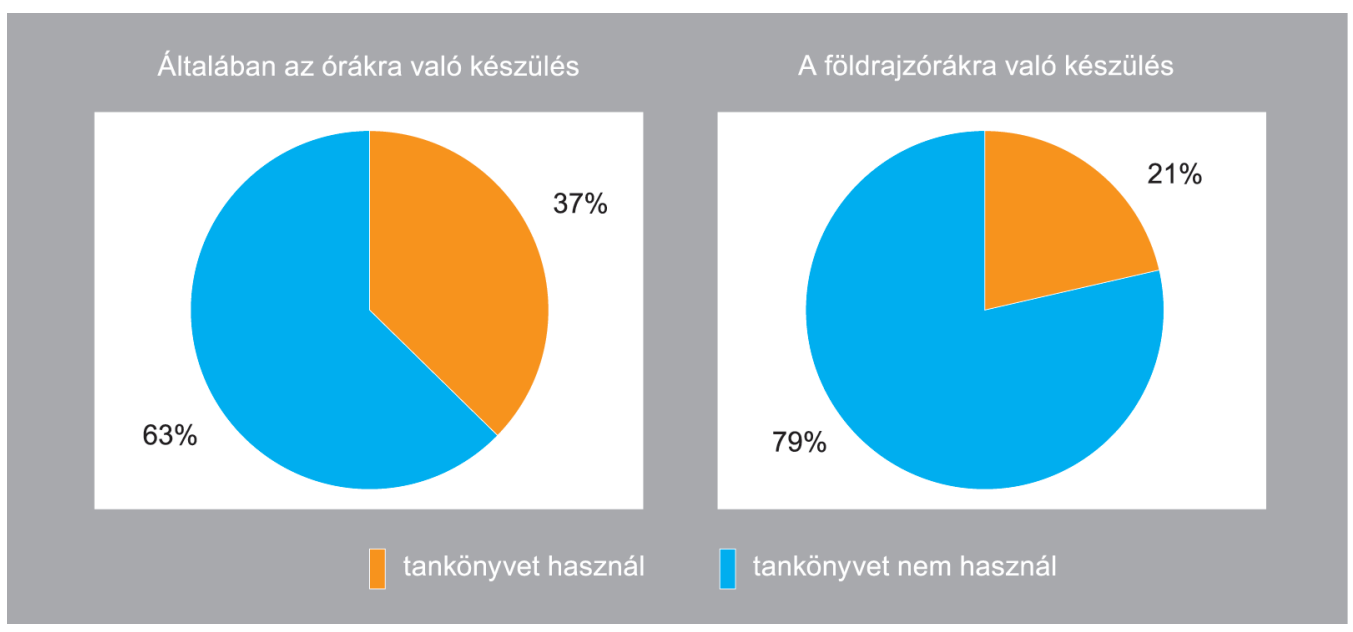

6. ábra. Tanórára való felkészüléshez tankönyvet használók és nem használók aránya (szerk. Gerlang V.) Tankönyvet használók: órai jegyzet és tankönyv, csak tankönyvi szöveg, tankönyvi szöveg, képek és ábrák, tankönyv jegyzetelése, egyéb. Tankönyvet nem használók: nincs otthoni készülés, csak órai jegyzet, órai jegyzet és internet. 
tankönyvi információhordozók az órákon fontosabb szerepet töltenek be, viszont az otthoni egyéni felkészülés során ez nem mondható el. Az eredmények azt mutatják, hogy a pedagógusok leginkább a házi feladatok forrásaként tekintenek a tankönyvekre, földrajzból viszont ennél fontosabbnak találják az ábrák közös tanórai elemzését. A tankönyvi feladatok órai megoldása általában igen népszerü, ellenben a földrajzórákkal, ahol nem kifejezetten gyakori.

\section{ÖSSZEGZÉS}

A kérdőívekre adott válaszok alapján elmondható, hogy a tanulók nem szívesen használják a tankönyveiket, a földrajzkönyvüket pedig még kevésbé vonják be a tanulási folyamatba. A tanórákon nem általános az, hogy ne legyen tankönyvhasználat valamilyen formában, viszont a földrajzórákon sokkal kisebb a tankönyvhasználati hajlandóság. Ebből arra is következtethetünk, hogy a pedagógusok sem szívesen alkalmazzák a földrajzkönyveket. Ugyan a mai földrajzkönyvek egyre inkább az aktív tanulói tevékenységre építenek, változatos feladatokat kínálnak, ezek használata mégsem képezi a tanítási órák szerves részét. A tanulók olyan könyvből tanulnának szívesen, aminek a szövege nagyon egyszerü, logikus, áttekinthető. Ez a kívánalom összefüggésben lehet a tanulók szövegértésével is, aminek szintje a nemzetközi mérések alapján hosszú évek óta OECD-átlag alatt van. Elképzelhető, hogy a mai felgyorsult világban kialakult gyakorlat is erősíti ezt, miszerint a tanulók erősen szelektálva csak azzal foglalkoznak, ami érdekli őket és ami kevés idő- és energiabefektetéssel hoz eredményt. Az mindenesetre pozitív, hogy lényegesnek tartják az informatív ábrákat a tankönyvekben, hiszen a mindennapi életük során is gyakran látnak táblázatokat, diagramokat, így ezek értelmezésére fel kell készülni az iskolában.

Tanulni sokféle forrásból lehet, a fontos az, hogy megtaláljuk azokat, amelyek hiteles információkkal szolgálnak. A tankönyvek egyik fö funkciója a megfelelő minőségü és mélységü tényanyag biztosítása a tanulók számára, ám a kutatás alátámasztja a kezdőhipotézist, miszerint használata a földrajz tanítása és tanulása során nem elsődleges, a tanulók szívesebben készülnek az órai jegyzetekből és az internet segítségével. Az eredményekből az is kitűnik, hogy a földrajzkönyvek használati gyakorisága elmarad a tantárgyak összességére vonatkozótól. Ennek oka igen összetett, erre irányuló kutatás nélkül felelőtlenség lenne bármit is állítani, azonban feltételezhetően összefüggésben van a földrajz tantárgy presztízsével és a tanulók motivációjával. Felmerülhet a kérdés, hogy ha a tanulók úgysem használják, szükség van-e egyáltalán földrajzkönyvre? Nehéz egyértelmú választ adni. Az oktatás akkor lesz sikeres, ha a szakmai szempontokat figyelembe véve (szaktárgyi sajátosságok, szakmódszertani és pedagógiai elvek), de a tanulók 
igényeit is szem elött tartva készülnek a taneszközök, megnyerve ezzel a pedagógusokat és a tanulókat egyaránt. Alternatívát jelenthet egy olyan digitális oktatási segédanyag, ami nem elsősorban tananyagfókuszú, hanem a kompetenciafejlesztést - beleértve a szövegértési készség fejlesztését is - és a komplex szemléletmód kialakítását célozza az aktív tanulói tevékenységeken keresztül.

A felhasználók számára legmegfelelőbb segédanyag kialakításához természetesen nemcsak a tanulók megkérdezése, hanem a pedagógusok igényeinek felmérése is szükséges. Ennek következtében további célom egy földrajztanárok körében végzett kutatás, ami az ő szemszögükből járja körül a problémát. Ennek segítségével kívánom felmérni, hogy jelenleg milyen gyakran és milyen tevékenységekkel kapcsolatban kerül elő a tankönyv a tanítási órákon, mit gondolnak, mely funkciókat képes a leginkább ellátni, milyen egyéb anyagokat használnak a tanítás során.

\section{IRODALOM}

Arday I. - Buránszkiné Sallai M. - Makádi M. - Nagy B. - Sáriné Gál E. (2018a): Földrajz 9. újgenerációs tankönyv. - EKE OFI, Budapest. 232 p. https://www.tankonyvkatalogus.hu/pdf/ FI-506010901_1_teljes.pdf (utolsó letöltés: 2020. 06. 10.)

Arday I. - Köszegi M. - MaKádi M. - Sáriné Gál E. - ÜtőNÉ Visi J. (2018b): Földrajz 10. újgenerációs tankönyv. - EKE OFI, Budapest. 257 p. https://www.tankonyvkatalogus.hu/pdf/FI-506011001_1__ teljes.pdf (utolsó letöltés: 2020. 06. 10.)

Áвraнám I. (1993): A tankönyv funkciói, szerkezeti elemei. Tankönyvmüfajok. - Kiadói ismeretek. Útmutató tankönyvszerzők és szerkesztők számára. - Korona Kiadó, Budapest. pp. 3-10.

Báthory Z. - Falus I. (szerk. 1997): Pedagógiai lexikon III. - Keraban Kiadó, Budapest. 694 p.

BERNEK Á. (2016): Az ember és a Föld. Földrajz a középiskolák 10. osztálya számára. - EKE OFI, Budapest. $208 \mathrm{p}$.

CsApó B. (2008): A taneszköz fejlesztés megalapozása: a tudásról való tudás. - In: SIMON M. (szerk.): Tankönyvdialógusok. OFI, Budapest. pp. 11-21.

Dringó-Horváth I. - Menyhei Zs. (2020): A nyelvkönyvpiac változásai - Nyelvkönyvcsaládokhoz kapcsolódó digitális tananyagok vizsgálata. - Új Pedagógiai Szemle 70. 1-2. pp. 51-82. http://upszonline.hu/resources/volumes/70/issues/01-02/upsz_70(01-02)_2020.pdf (utolsó letöltés: 2020. 06. 07.)

GÉCZINÉ LASKAI J. (2010): A tankönyv lehetséges funkciói a gyakorlathangsúlyos tantárgyakban és a tanulási folyamatban. - Training and practice 8.3-4.pp.97-109. http://trainingandpractice.hu/sites/default/ files/kepzes_es_gyakorlat/tanulmanyok/07-Geczine-tanulmany.pdf (utolsó letöltés: 2020. 06. 07.)

KAPosi J. (2012): A tankönyv szerepének változásai. - Iskolakultúra 22. 12. pp. 56-70. http://epa.oszk. hu/00000/00011/00171/pdf/EPA00011_iskolakultura_2012_12_056-070.pdf (utolsó letöltés: 2020. 06. 07.)

Karlovitz J. (2000): A tankönyv funkciói. http://taneszkozfigyelo.fw.hu/tanfigy5/tkfunkcioi.html (utolsó letöltés: 2020. 06. 07.) 
KARLovitz J. T. (2000): Tankönyvi, tankönyvelméleti alapfogalmak. - Könyv és Nevelés 2. 2. https://epa. oszk.hu/01200/01245/00006/cikk7.html\#sdfootnotelanc (utolsó letöltés: 2020. 06. 07.)

Kereszty P. - Nagy B. - Nemerkényi A. - Neumann V. - Sárfalvi B. (2014): Lakóhelyünk a Föld. Földrajz a középiskolák 9. osztálya számára. - EKE OFI, Budapest. 156 p.

KoJANiTz L. (2004): A tankönyvek használhatóságát meghatározó minőségi összetevők elemzése és összehasonlítása. - Nemzeti Erőforrás Minisztérium, Budapest. 49 p. http://www.nefmi.gov.hu/letolt/ kozokt/tankonyvkutatasok/cd1_kojanitz/vizsgalat_eredmenyeinek_bemutatasa.pdf (utolsó letöltés: 2020. 06 .07.)

Kojanitz L. (2007): A tankönyvek minőségének megítélése. - Iskolakultúra 17. 6-7. pp. 114-126. http:// real.mtak.hu/56985/1/EPA00011_iskolakultura_2007_06_07_114-126.pdf (utolsó letöltés: 2020. 06. 07.)

MAKÁDI M. (2019): Kell-e tankönyv a földrajztanuláshoz? Az újgenerációs földrajztankönyvek koncepciója. GeoMetodika.3. 1.pp. 79-88. http://foldrajztanitas.elte.hu/index.php/2019/01/21/kell-e-tankonyv-a-foldrajztanulashoz-az-ujgeneracios-foldrajztankonyvek-koncepcioja/ (utolsó letöltés: 2020. 06. 07.)

Nagy B. - Nemerkényi A. - SÁrfalvi B. - Ütőné Visi J. (2018): Földrajz 9. - EKE OFI, Budapest. 216 p.

NÁDAsi A. (2014): Az oktatástervezés és -technológia aktuális kérdései és trendjei. Elektronikus könyv, EszterházyKároly Főiskola,Eger.https://regi.tankonyvtar.hu/hu/tartalom/tamop412A/2011-0021_24_ az_oktatastervezes_es_technologia_aktualis_kerdesei_es_trendjei/index.html (utolsó megtekintés: 2020. 06. 09.)

Paivio, A. (2007): Mind and its evolution. A dual coding theoretical approach. - Lawrence Erlbaum Associates, Mahwah. 507 p. https://core.ac.uk/download/pdf/60529881.pdf (utolsó letöltés: 2020. 06. 07.)

ProbÁld F. - ÜtőNÉ VISI J. (2014): Földrajz 10. - EKE OFI, Budapest. 240 p.

PISA 2018. Összefoglaló jelentés. Oktatási Hivatal, Budapest. 99 p. https://www.oktatas.hu/pub_bin/ dload/kozoktatas/nemzetkozi_meresek/pisa/PISA2018_v6.pdf (utolsó letöltés: 2020. 06. 07.) 